Lawand Wirya Shawkat ${ }^{1}$

Salar Salah Muhy Al-Din ${ }^{2}$

Duško Kuzović ${ }^{3}$
JEL: Q01, Q20, L74, L78, N95

DOI: $10.5937 /$ industrija45-14845

UDC:

Original Scientific Paper

\title{
Leed rating system barriers in the construction sector in Northern Iraq
}

\author{
Article history: \\ Received: 22 August 2017 \\ Sent for revision: 1 September 2017 \\ Received in revised form: 21 November 2017 \\ Accepted: 21 November 2017 \\ Available online: 25 December 2017
}

\begin{abstract}
Northern Iraq (federal part of Iraqi Federal Republic) has witnessed a huge development in construction sector last ten years. However, there are lack of awareness and legislation regarding the sustainable construction in the building sector. The impact of construction technologies became a challenge front the serious problems of environmental crisis. The aim of the paper is to find the required mechanism to introduce sustainable practice and implement sustainable construction in the building construction sector. The main objectives in the paper are: identify the barriers in sustainable construction; investigate the law and regulations in dealing with these barriers; evaluate the application of LEED rating system in the construction sector. The research method in the paper is based on literature review and professional opinion through questionnaire. The paper list the most important barriers for implementing sustainable construction, the suggestions to apply LEED rating system, and recommendations to improve and develop sustainability in construction sector at Northern Iraq.
\end{abstract}

Keywords: Green Rating Systems, LEED, Sustainable Construction, Sustainable Construction Barriers, Northern Iraq.

\section{Prepreke za primenu „leed“ sistema vrednovanja u građevinskom sektoru Severnog Iraka}

Apstrakt: Severni Irak (federalna jedinica Federalne Republike Irak) beleži ogroman razvoj u građevinskom sektoru u poslednjih deset godina. Uticaj

\footnotetext{
${ }^{1}$ Girne American University, Faculty of Engineering,TRN Cyprus, lawandw@gmail.com ${ }^{2}$ Girne American University, Faculty of Architecture, TRN Cyprus

${ }^{3}$ Dhofar University, College of Engineering, Salalah, Sultanate of Oman
} 
Wirya Shawkat L. et al.: Leed rating system barriers in the construction sector In...

savremenih građevinskih tehnika, zajedno sa energetskom krizom, otvara front ozbiljnih problema u praksi. Rezultat rada treba da definiše potrebne mehanizme uvođenja održive prakse $i$ implementacije održive gradnje $i$ građevinskom sektoru. Glavni ciljevi rada su: identifikovati barijere za održivu gradnju; istražiti zakone i regulativu u odnosu na navedene barijere; proceniti primenu "LEED" sistema vrednosvanja u građvinskom sektoru. Istraživački metod $u$ radu je baziran na literaturi i profesionalnom mišljenju prikupljenom kroz upitnik. Rad daje popis mogućih barijera za implementaciju održive gradnje, sugestije za primenu "LEED" sistema vrednovanja, i preporuke za unapređenje i razvoj održivosti u građevinskom sektoru Severnog Iraka.

Ključne reči: Zeleni sistem vrednovanja, LEED, Održiva gradnja, barijere za održivu gradnju, severni Irak.

\section{Introduction}

Late of twentieth century, the effect of Technology and the extending human populace on the Earth turned into a challenge. Today the world is facing serious problems of global warming and climate changes. For decades, the environmental impacts of the construction industry have been overlooked such as unreasonable consumption of resources in addition to producing a lot of construction waste. The greenhouse gas (GHG) emissions generated from building sectors, which is the main factor in accelerating climate change. The building sector expends around $40 \%$ of all created energy around the world (Ozdil, 2010). People began to increase their potential to reduce their effect on the environment. The awareness towards the sustainable development issues as a solution to overcome these challenges, leads to focus on the sustainable construction practices, taking into consideration the human safety and environment condition. Reducing Construction sector's energy consumption is a significant issue to overcome the challenges of the climate change.

Northern Iraq is a federal part in federal state of Iraq and consist of four governorates: Erbil, Slemani (including administration of Garmian), Duhok, and Halabja (added 2014). This include the governorates administered by $K R G$, but does not contain areas of Kurdistan outside of KRG administration, such as Kirkuk (Soderberg \& Phillips, 2015). The population of Northern Iraq region is 5,2 million citizens. Region covers approximately 40,000 square kilometers. The region bordered by Turkey from the north, by Iran from the East, by Syria from the west and from the south by the rest of Iraq. The capital of the region is city Erbil. The construction sector is a big part of the Northern Iraq Region's economy. The span of the development market is evaluated at $\$ 2.8$ billion, with $95 \%$ of the market controlled by Turkish construction 
Wirya Shawkat L. et al.: Leed rating system barriers in the construction sector In...

companies. According to ECU ("Erbil Contractors' Union"), the total numbers of construction contractors in the region is estimated by 2,500 contractors, there are 59 foreign Members out of that, 51 of them are Turkish and 8 are Iranian. "The Turkish Daily News" mentioned that the total numbers of the Turkish contracting companies are estimated by 634 companies working in Northern Iraq, (USAID, 2008). Building costs rising progressively in Northern Iraq, because of the rising of prices of fuel, materials, as well as labors. Since 2000 , steel-bars have increased from $\$ 200$ per ton to reach $\$ 700-\$ 800$ per ton in 2008. Also, the cost of cement increased from $\$ 25$ per ton to $\$ 125-$ $\$ 150$ per long ton. According to the Contractor Union in Northern Iraq asserted, that the construction costs have increased 6 time over 10 years (USAID, 2008). (Figure 1)

Although the region is abundant with energy sources (oil and gas), most of the expert population believes that rational behavior in this domain is necessary. Therefore, it is necessary to establish legal frameworks / standards and then find the necessary ways to implement new solutions. Therefore, research of possible barriers of multiple importance for the proper definition of the plan and program of application of legal solutions. Education, local selfgovernment, ministries and economy (design and construction) have been identified as the most important areas on the road to good application. Accordingly, 25 interviewers have been selected for proportional representation of those areas (Ministry, municipalities, faculties, design firms, construction companies, real estate dealers).

The region started to jump with giant leaps in the last decade in the field of construction. Many foreigner companies from all around the world are working there. Employing and applying Green Building Rating systems will help the region to get global reputation and should to be considered as international place and have a foreground in the region in this field. The government of the region is one of the most effective factors to achieve this goal.

The main purpose of this paper is to investigate the use of the environmental classification system The "Leadership in Energy and Environmental Construction" LEED as assessment instruments for the possibility of sustainable construction performs in Northern Iraq. The main barriers front of sustainable construction practice in Northern Iraq will be identified, through the statistical analysis of questionnaire results. As a final outcome the paper suggest a number of recommendations that should be done to create projects with green rating system such as LEED in Northern Iraq. These suggestions could include: changes in the present legislation and specification; the presentation of new arrangement, for example, a construction law and real changes to the energy regulation system like the revision of the utility costs as well as energy prices. 
Wirya Shawkat L. et al.: Leed rating system barriers in the construction sector In...

\section{Methodology}

The methodology of the paper is in the interrelation between three parts: literature review, interviews and case study.

1. Literature review: The research will approach the literature to reach intelligible understanding about the related information about the research. And to find the main hinders in implementing sustainable construction.

2. Questionnaire: Qualitative and quantitative questionnaire will be conducted, to evaluate sustainable construction in the building and address the difficulties and the solutions to apply it in construction industry in Northern Iraq.

3. Case studies: Investigate a case study rating system in order to improve the knowledge for sustainable building construction in Northern Iraq, and find the possibility of applying these rating systems at Northern Iraq.

Green building rating systems will be elucidate, in order to have intelligible understanding about the rating systems around the world. Leadership in Energy and Environmental Design (LEED), as one of the most applied rating system in the world. The existing obstacles and difficulties to apply sustainability in construction management in Northern Iraq and Middle East should be overviewed through Documentation and Discussion part of the paper.

Questionnaire used in several types of researches such as survey research, experiments and other modes of observation. "Closed- ended" and "openedended" question has been used to design the questionnaire for identifying the most important barriers to apply sustainable construction in Northern Iraq.

Quantitative and qualitative method will be conducted in the questionnaire (on the sample of 25) through answering several of academic lecturers and staff about their evaluation of the barriers to achieve sustainable construction through rating each barrier by 6 scores (Highly Agree $=6$ score; Agree $=5$ score; Slightly agree $=4$ score; Slightly disagree $=3$ score; Disagree $=2$ score, Highly Disagree $=1$ score). The professional opinions about the main barriers to apply sustainability in building construction was asked to be added by the participant in order to find that is not listed as a part of the qualitative approach in the questionnaire. The questionnaire will also, ask the participants to give their opinion about the existing situation of sustainability in the construction sector in Northern Iraq will be investigated.

The barrier facing the sustainable construction had been investigated in the literature and the most significant factors have been listed according to the previous studies and researches. This list has been involved in the questionnaire form to be rated by the participants as explained previously. 
Wirya Shawkat L. et al.: Leed rating system barriers in the construction sector In...

First factor "Initial Cost for the building" is the indicator of primary cost of the building regardless the payback or recovery after the usage of the building. Second factor, "Political and Governmental Issue", refers to the lack in government law and support, deficiency in building construction specification and codes on sustainability. Third factor, "The awareness and knowledge about sustainability", refers to the shortage of professionals, and shortage in sustainable design potential. The Fourth factor, "Socio-Cultural factor", refers to the society resistance to change the traditional way in construction procedure, and lack in the demand on sustainable products. The fifth factor, "Technical Issue", refers to lack in technical potentials, skills and sustainable materials. The sixth barrier, "Leadership and Management Factor", affects the construction industry and individual organizations to achieve successful strategies in sustainable construction.

The results of the data that obtained from the questionnaires were implemented by employing the software. The results were converted into descriptive results, which applied for drawing an achievable conclusion.

A questionnaire was handed out to a population of 25 participants and the filled questionnaires were obtained from the respondents within almost one month. The questionnaires were distributed across professionals in the field of building construction and the field of sustainable buildings and designs, as well as practitioner Engineers and Architects in the field of construction. 20 questionnaire forms were returned back from 25 questionnaire distributed, which indicates that the responding rate was $80 \%$. It also included cost and economy problems. The data will be studies in more details and analyzed based on statistic, graphical and mathematical basis.

Case study method is a method that gives the researcher the potential to examine the data within a specific context closely (Zainal, 2007). According to Bromley (Bromley,1990) a case study method can be defined as: a systematic requirement from and subject of the interest in order to explain the interested phenomenon. LEED, as the most prevailed rating system around the world, (Appleby, 2011), was selected as a case study to be applied in Kurdistan region of Iraq. The analysis based on this rating system was approached through literature review as; library sources as books, internet valid sources, such as articles, papers and researches to understand the characteristic of this rating system. The barriers to sustainable construction practices which have been obtained through the questionnaire will be compared with the requirement in this rating system. The compatibility of this rating system factors will be examined based on expert's opinion through the questionnaire to identify the weakness and merit of this system for Northern Iraq.

The Northern Iraq is one of the new Federal parts of Iraqi Federal Republic. The region started to jump with giant leaps in the last decade in the field of construction. Many foreigner companies from all around the world are working 
Wirya Shawkat L. et al.: Leed rating system barriers in the construction sector In...

there. Employing and applying Green Building Rating systems will help the region to get global reputation and to be considered as international place and have a foreground in the region in this field. The government of the region is one of the most effective factors to achieve this goal

Figure 1. Map of Northern Iraq Region, Republic of Iraq

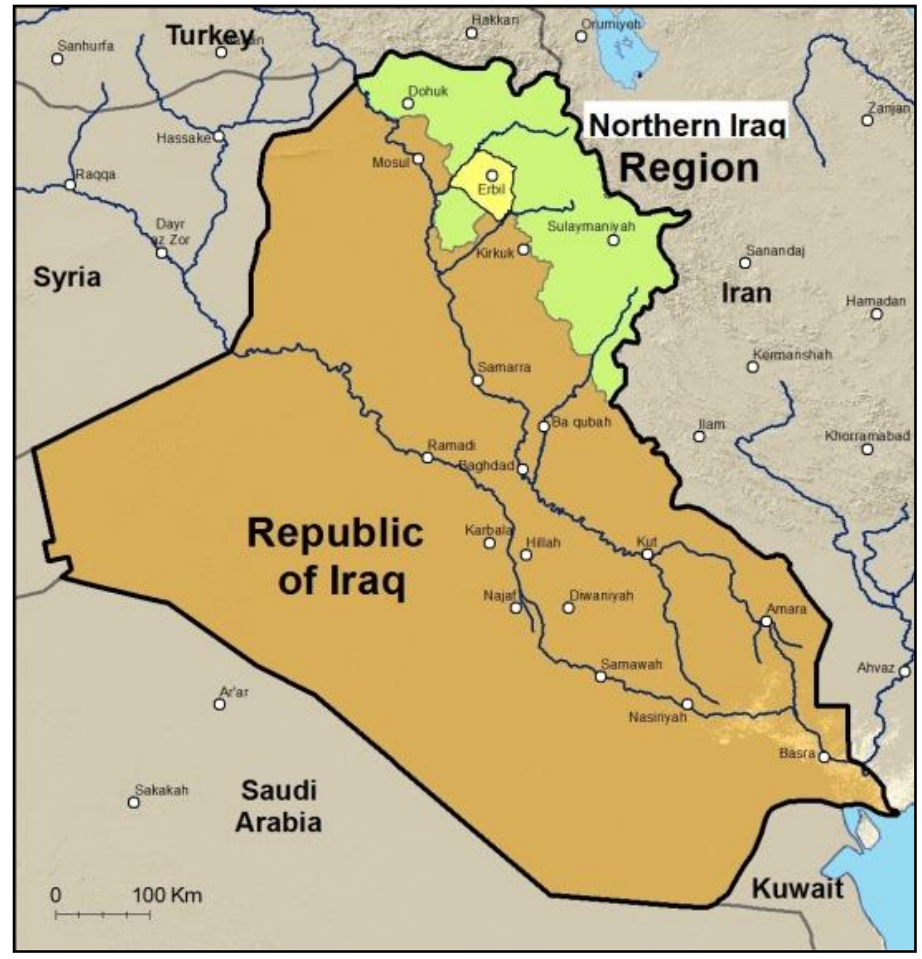

Source: http://www.iran-daily.com/News/155384.html)

\section{Literature review}

\subsection{Sustainability in construction}

The necessity to overcome the global warming and climatic changes, which the world facing it in $21^{\text {st }}$ century, requires the action towards sustainability are crucial subject nowadays. Growth population and expanding of urbanization will continue increasing the buildings construction. In the same context, the needs for the safe and good life of future generations are also important. To reach this goal there is vital requirement to control urban planning, design and 
Wirya Shawkat L. et al.: Leed rating system barriers in the construction sector In...

construction. Thus, sustainability in design and construction became crucial for the storing of natural resources for next generations. United Nations World Commission on Environment and Development (UNWCED), defined Sustainability was defined as that which:

"...meets the needs of the present without compromising the ability of future generations to meet their own needs." (1987), (Al Surf, 2014)

Sustainable development and construction of the buildings are directly affect one another, as Section 7.67 of the United Nations' Agenda 21 states:

"The activities of the construction sector are vital to the achievement of the national socio-economic development goals of providing shelter, infrastructure and employment. However, they can be a major source of environmental damage through depletion of the natural resource base, degradation of fragile eco-zones, chemical pollution and the use of building materials harmful to human health" (UN-Agenda 21, 2004).

Sustainability consists of three main aspects, the interrelation of them creates the sustainability. Sustainable development recognized in three terms, that are environmental protection, economic growth, and social development (Adams, 2006). These aspects should be available in order to achieve sustainability in any field (Figure 2).

Construction of the buildings development can be considered one of the most significant issues for sustainable development, because of its long life-span and its direct and indirect impact on human's life. Despite that building construction is one of the more important ways to reach the goals of sustainability. However, the researches Winston and Eastaway (Winston \& Eastaway, 2008) addressed that it is one of the more neglected aspects of sustainability. Hence, it is important to find ways to create sustainable construction in the buildings. The character of sustainable building is costefficient over time period, eco-friendly, and comfortable. The sustainable building should ensure that it will have less impact of the occupant's health with less impact on Nature. Generally sustainable buildings supposed to achieve the three main aspects of sustainability: a) Environmental sustainability, b) economic sustainability and, c) Social sustainability (McConville, 2006). Table 1, shows the main factors to achieve sustainability in the buildings considering the three aspects of sustainability. 
Wirya Shawkat L. et al.: Leed rating system barriers in the construction sector In...

Figure 2. Three main aspects of sustainability

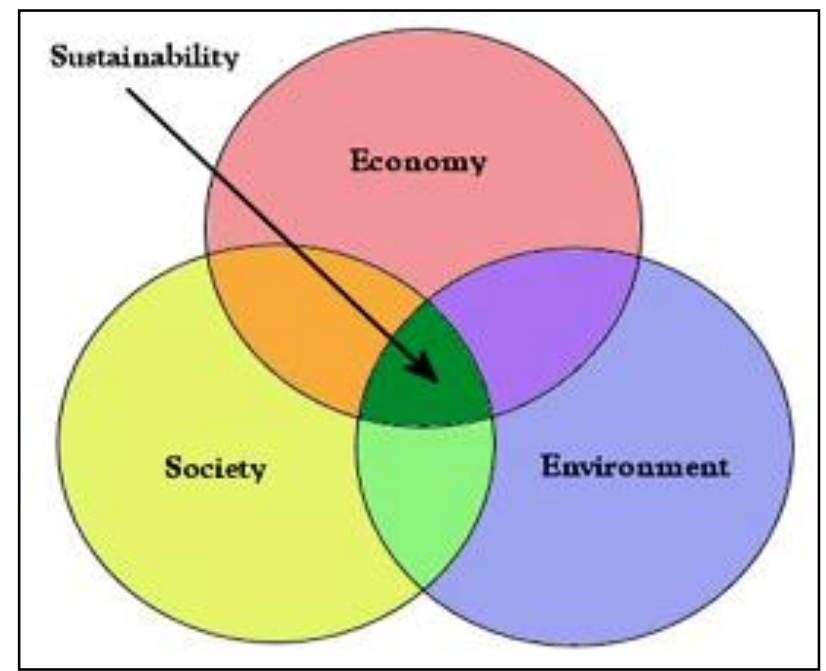

Source: Juneau Commission on Sustainability:

http://www.juneau.org/clerk/boards/Sustainability/about/about-sustainability/what-issustainability.php [Retrieved] on 3rd of March, 2017 from IFMA Environmental Stewardship and Sustainability

Constructions, involves into socio-economic fields and environmental field as well, through making remarkable use of natural resources and increase the generation of greenhouse gasses through buildings (Asif et al., 2005). According to Zainulabidin and Pasquire (Zainulabidin \& Pasquire, 2005), the main principles in sustainable building are to implement the safety and comfort to occupants as well as the surrounding environment and society.

The different interpretation of the "construction" by the researchers made the definition of it a complex issue (Du Plessis, 2007). Some researchers defined the "construction" as: all the corporations, which involves in the design and construction of buildings directly (Bosher et al., 2007).

According to Du Plessis (Du Plessis, 2007), the interpretation of the "construction" could be done by two main ways. The first is the activity level of the site; it is most narrow definition of construction, which deciphers development just as the site exercises to develop the facilities of the construction. The second is whole project cycle; it is broader perspective, which signifies the involvement of the many aspects like, manufacturers, providers and directors that assume essential parts in the development business. However, the relation issues to the business of construction and the process of establishing human settlement are involved as well. This way is the concern of this research, where refer to sustainable construction. 
Wirya Shawkat L. et al.: Leed rating system barriers in the construction sector In...

Some authors, in their definitions have referred to sustainable construction as the design and construction phases only (Hendriks, 2001). However, general definition of sustainable construction should include the property and its management (Pearce, 2003). Thus, Parkin (Parkin, et al., 2000), asserted that the sustainable construction is the issue of the life cycle of the "construction", beyond the only lifetime of the "project" has been. Hill and Bowen (Hill \& Bowen, 1997) note that, despite sustainable construction describes a procedure that begins before the physical development in construction stage and proceeds after that. According to some researchers "lifecycle" defines the "instance of existence" for an object or entity on specified scale (Edum and Price, 2009). Huovila and Richter (Huovila \& Richter, 1997) assert that sustainable construction is the processes and products that, goes for limiting the utilization of energy and outflows that are hurtful for condition and wellbeing during their functional life.

Table 1: The elements to achieve the three dimension of sustainability

\begin{tabular}{|c|c|c|}
\hline \multicolumn{2}{|c|}{ Economic Sustainability } & $\begin{array}{l}\text { Implies that sufficient local resources and capacity exist } \\
\text { to continue the project in the absence of outside } \\
\text { resources. }\end{array}$ \\
\hline \multicolumn{2}{|c|}{ Environmental Sustainability } & $\begin{array}{l}\text { Implies that non-renewable and other natural resources } \\
\text { are not depleted nor destroyed for short-term } \\
\text { improvements. }\end{array}$ \\
\hline \multirow{3}{*}{ 宽 } & Socio-Cultural Respect & $\begin{array}{l}\text { A socially acceptable project is built on an } \\
\text { understanding of local traditions and core values. }\end{array}$ \\
\hline & $\begin{array}{l}\text { Community } \\
\text { Participation }\end{array}$ & $\begin{array}{l}\text { A process which fosters empowerment and ownership } \\
\text { in community members through direct participation in } \\
\text { development decision-making affecting the community. }\end{array}$ \\
\hline & Political Cohesion & $\begin{array}{l}\text { Involves increasing the alignment of development } \\
\text { projects with host country priorities and coordinating } \\
\text { aid efforts at all levels (local, national, and } \\
\text { international) to increase ownership and efficient } \\
\text { delivery of services. }\end{array}$ \\
\hline
\end{tabular}

Source: (McConville, 2006)

Previously many institutes and researchers such as; UNEP (UNEP,2003), Huovila and Richter (Huovila \& Richter,1997), have viewed sustainable construction as an environmental issue. Consequently, this made many researchers to consider sustainable construction as a good environmental management, but this understanding of sustainable construction has been changed over the years. In the beginning they focus on the resources depletion subject through energy consumption, and reducing the impact on environment. Therefore the technical solutions through building material, and design concept were the goals (Sjostrom \& Bakens,1999). 
Wirya Shawkat L. et al.: Leed rating system barriers in the construction sector In...

When sustainable construction have been understood as application for the principles of the sustainable development in construction sector, then it is generally accepted that similar to SD, sustainable construction addressed the three aspects of environmental, social and economic elements. Hence, and according to Gunatilake (Gunatilake,2013), some of extra components have been considered by several researchers in different studies. These elements are: 1. Environmental/ Ecological/ Biophysical, 2. Social, 3. Economical, 4. Institutional, 5. Legal, 6. Political, 7. Cultural, 8. Technical, 9. Managerial, 10. Community, 11. Moral.

Some other researchers use additional elements, such as Liu, (Liu, 2006) who used two different components (socio-economic) which refers to the construction process participants behavior in procuring assembled resources and socio-environmental, (refers to the social and environmental aspects). These two elements used in place of the more common three aspects (environmental, social, and economic).

\subsection{Green Building}

There are many definitions for "Green Building". Green Building can be defined as, the building whose construction and operation lifetime assure the most efficient and least degradation use of land, efficient use of water, energy and resources, and offer the healthiest environment (Gunatilake,2013). The best design solution is that simulate all of the natural systems and conditions before site development and after the development, effectively.

Green building were described according to Office of Federal Environmental Executive as: the process or application that increase the efficiency within buildings and their sites in usage of energy, water and material, and the buildings which reducing the impacts on the environment and human health. This could be achieved through better sitting, design, construction, use, maintenance, and demolishing (U.S. Green Building Council, 2006).

Different terms were used by the researchers to address the same meaning. For example, Robichaud and Anantatmula (Robichaud \& Anantatmula, 2011) mentions that green building is also giving the meaning of sustainable construction, and "High performance building", or "Sustainable building". In general the sustainable construction leads to achieve green building in the same time high performance and sustainable one.

In UK In 1990, the Building Research Establishment, LLC (BRE) made an environmental evaluation technique BREEAM, (BREEAM, 2009). Fourteen countries (Canada, Austria, Denmark, Finland, Poland, France, Japan, Norway, Sweden, Germany, Switzerland, Netherlands, United States, and United Kingdom), in 1996 started to develop technique known as the "Green Building Challenge". The aim was to develop and apply a system for 
Wirya Shawkat L. et al.: Leed rating system barriers in the construction sector In...

measuring the performance in the buildings environmentally and through energy issues. The Green Building Challenge proceeded with its advancement through 2000 to 2005, and come about of the advancement was the "GBTool". It is an apparatus to help in the environmental assessment of buildings. "Green Building Challenge" became presently the 'Sustainable Building Challenge" and proceeds to develop the process about environmental building implementation performance and green building design (iiSEBE, 2009). Many other green rating systems have been created in many countries based on BREEAM, based on the needs of a country through environmental perspective.

Figure 3. Rating system based on their development timeline

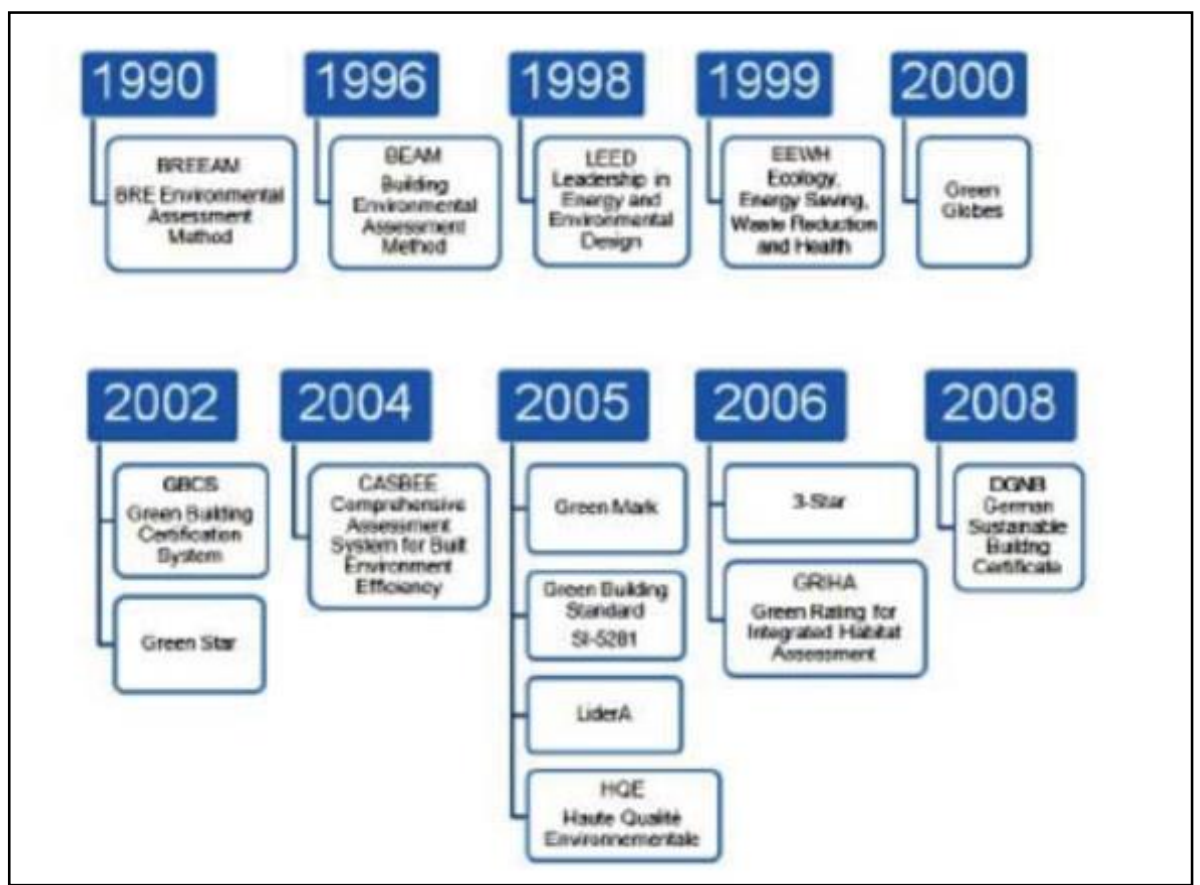

Source: on 3rd of March, 2017 from IFMA Environmental Stewardship and Sustainability Strategic Advisory Group (ESS SAG): http://cdn.ifma.org/sfcdn/membership-documents/greenrating-systems-htg-final.pdf)

Rating systems evolved in coming years according to two main factors (user feedback and the technology development) in order to enhance the achievement of buildings in term of environmental level. Green rating systems started as a voluntary measure of environmental performance. Nowadays certification is recommended for buildings in many countries. Currently, there 
Wirya Shawkat L. et al.: Leed rating system barriers in the construction sector In...

are fifteen rating systems that give certifications to buildings performance around the world (Figure 3). Only three systems of them are using currently for structures outside of their nations of origin, there are: Leadership in Energy and Environmental Design (LEED), BREEAM, and Green Globes.

\subsection{Leadership in Energy and Environmental Design (LEED)}

The Leadership in Energy and Environmental Design (LEED) rating system is green building program in the U.S. and it is not the first. But it is the only program that has been applied by many private organizations and government bodies inside USA. The U.S. Green Building Council (USGBC) is a voluntary organization that was founded in 1993. It is established by engineers, architects, contractors, building material manufacturers, and environmental groups who are keen on creating of green working in the United State. The members of this council developed a system to evaluate green buildings by mean of researching existing programs like, the British BREEAM and Canadian BEPAC, in order to establish proper system for United States buildings. Then, in 1998 the LEED 1.0 pilot program was released, and until March 2000, twelve buildings in United States were had certified under this pilot program. Nowadays, hundreds of buildings certified and demonstrating investment by millions of dollars and thousands of hours of time, all with the goal of improving the performance of buildings environmentally. LEED is a rating system to evaluate building environmental performance from a whole building taking in consideration whole lifetime of building, in order to provide a standard for 'green building' identifying (DOE, 2001). (Kirk \& Dell'Isola, 1995) states that, according USGBC, the reason for finding LEED was:

1. Attain positive impact on environment, building user health and financial saving,

2. Provide a standard for measurement to define "green",

3. Prevent "green washing" (false or exaggerated claims),

4. Improve the building integrated design processes,

LEED rating is based on a credit system. It consists of 64 credit points, divided on five environmental impact areas:

1. Sustainable Sites (SS),

2. Water Efficiency (WE),

3. Energy and Atmosphere (EA),

4. Materials and Resources (MR),

5. Indoor Environmental Quality (IEQ).

Also it contains of other 5 credit points for "Innovation and Design Process (ID)" activities. In four of the above areas there are prerequisites, that each building must have it and a few credit alternatives in every zone. Some credits 
Wirya Shawkat L. et al.: Leed rating system barriers in the construction sector In...

have many layers to increase the performance achievements. A minimum of 26 points must the building implement in order to get a LEED certification (in addition to all the prerequisites), and the grade is as shown:

1. 33 to 38 points - "Silver rating",

2. 39 to 51 points - "Gold rating",

3. 52 to 69 points - "Platinum rating".

Every credit in LEED rating system has requirements, depiction of plan, and documentation submitting. For a lot of conditions there is a referenced standard and credit figuring techniques. Credit prerequisites are included by economic information description, environmental and group components identified with the credit. The process of LEED rating system consists of the registration of a building project, achievement of the credit requirements, then submitting the documents. Extra expenses for the LEED accreditation prepare could cost tens of thousands of dollars (ATHENA, 2001). LEED has several versions such as LEED-BD+C for building design and construction, Building Operation and Maintenance, Interiors Design and Construction. There is also, LEED for homes, which started in 2008, and concerning housing developments design applications in different scales and sizes. Another version of LEED has started in 2009 for Neighborhood Development, (Appleby, 2011). (Figure 4)

Figure 4. Type of LEED versions

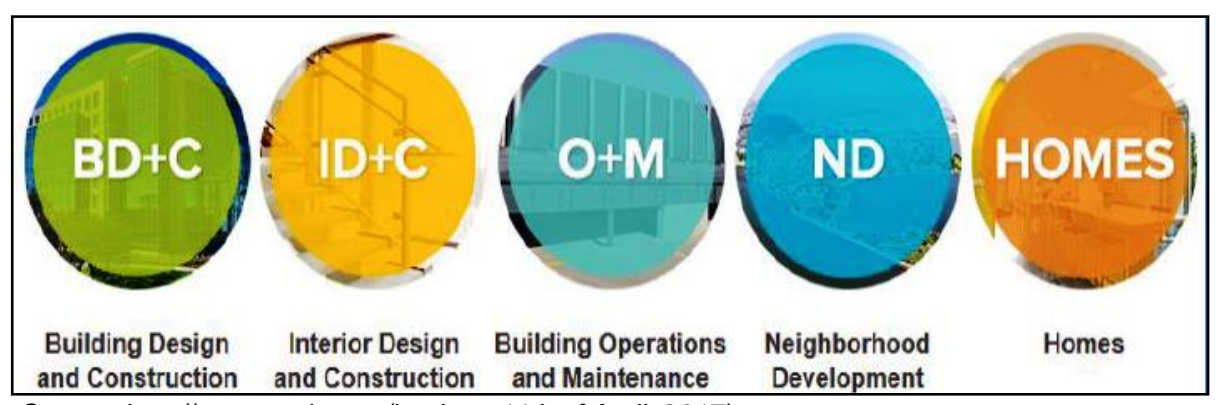

Source: http://www.usgbc.org/leed, on 11th of April, 2017)

\section{Discussion}

\subsection{Barriers to achieve sustainable construction practices}

Based on analysis of interview carried on the sample of 25 highly skilled people (Architects, Sustainable construction engineers, Construction managers, Sustainable Architecture biros, Structural Engineers) the results 
Wirya Shawkat L. et al.: Leed rating system barriers in the construction sector In...

showed that the most important barriers are: Initial cost for the building constructions (20/25 highly agree), political and government issues (20/25 highly agree), The awareness and knowledge about sustainability (12 highly agree, 6 agree, 2 slightly agree), Socio-cultural factor sustainability (10 highly agree, 6 agree, 4 slightly agree), technical issues (16 highly agree, 4 agree), leadership and management factor (19 highly agree, 1 agree).

There are several factors that could make barriers to achieve sustainable construction, and one of the main those factors are cost factor. In common sustainable buildings cost more than ordinary buildings through initial cost by around $2 \%$ to $7 \%$ (Castillo and Chung, 2005). Some projects can recover that extra cost through short time pay back. Awareness about sustainability and teaching stakeholders to think about value more than cost and think in the direction of long-term instead of short- term could overcome the problem.

The political factor is another important factor, which refers to the deficiency in government legislations or support, lack of building construction specification and codes on sustainability (Rydin, et al., 2006). The successful sustainable construction is highly depending on the government commitment in addition to the regulation and legislation. There are many benefits regarding sustainable construction, hence, governments should encourage and incorporate sustainable construction practices in construction projects to stimulate private sectors and individuals to act in the same way (Dzokoto \& Dadzie, 2013).

Table 2. The main barriers in achieving Sustainable Construction

\begin{tabular}{|c|l|l|}
\hline & $\begin{array}{c}\text { The main Barriers to achieve sustainable } \\
\text { construction }\end{array}$ & \multicolumn{1}{c|}{ References } \\
\hline 1 & Initial Cost for the building & (Castillo and Chung, 2005). \\
\hline 2 & Political and Governmental Issue & $\begin{array}{l}\text { (Rydin, et al., 2006); } \\
\text { (Dzokoto and Dadzie, 2013) }\end{array}$ \\
\hline 3 & $\begin{array}{l}\text { The awareness and knowledge about } \\
\text { sustainability }\end{array}$ & $\begin{array}{l}\text { (Häkkinen, \& Belloni, 2011); } \\
\text { (Williams and Dair, 2007) }\end{array}$ \\
\hline 4 & Socio-Cultural Factor & (Williams and Dair, 2007) \\
\hline 5 & Technical Issue & (Nelms, et al., 2005) \\
\hline 6 & Leadership and Management Factor & (Osaily, 2010) \\
\hline
\end{tabular}

Source: Authors

The awareness and knowledge about sustainability have significant impact on the implementation of sustainable construction (Häkkinen\&Belloni, 2011). This factor refers to the shortage of professionals or professional knowledge, also un-awareness of clients to the benefits of applying the sustainability, or the misunderstanding about sustainability. In additional to that, shortage in knowledge about sustainable design. Williams and Dair (Williams \& Dair, 2007), in their research addressed that the hindrance front of applying 
Wirya Shawkat L. et al.: Leed rating system barriers in the construction sector In...

sustainable construction is a shortage in stockholders awareness about sustainable measures that fall within their career field.

Socio-Cultural factor is one of the barrier fronts of implementation sustainable construction. This can be realized through the deficiency in the demand on sustainable products by the client. This refers to the society resistance to change the traditional way or concepts in construction ways (Williams \& Dair, 2007).

The technical factor is one of the barriers which have significant effects on sustainable construction. The lack of sustainable materials or eco-friendly materials, also, the shortage of sustainable measurement tools, lack in technical potentials, skills and labor experience shortages (Nelms, et al., 2005). The leadership and management factor is another barrier in the way of achieving sustainable construction. It affects the construction industry and individual organizations to implement successful creative strategies, (Osaily, 2010)

\subsection{Green Building Rating Systems and the Middle East countries}

LEED and BREEAM in addition to other green building rating system are used around the world. Sustainability became an important issue in the Middle East countries especially Arab Gulf countries like United Arab Emirates and Qatar, where formulate their own green building rating system to respond to their environmental, socio-economic, and cultural aspects in modern buildings and construction sector.

The Emirate of Abu Dhabi is applying PRS (Pearl Rating System), which is the green building rating system prepared for sustainable development process starting from design, through construction to operation in several scales from buildings and villas to communities. It is a guidance and requirements to rate a project with respect to sustainability or (Estidama). The rating system is an initiative of the part of Abu Dhabi government, in order to improve the life of people and reduce the impact on environment. PRS focusing on the cultural and traditional values and it is specified to the climate of Abu Dhabi which needs high energy consumption to achieve thermal comfort in the buildings, and characterized by scarcity of potable water. The Pearl Rating System has several grades ranging from one to five pearls. PRS Rating System is arranged in seven types, contain mandatory and optional credits. To implement a 1 Pearl rating, the total mandatory credit requirements must be achieved (Zafar, 2016). GSAS (The Global Sustainability Assessment System), when before was known as QSAS (the Qatar Sustainability Assessment System). It is a green building rating system developed for GCC (Gulf Cooperation Council countries). GSAS was established in 2010, by GORD (Gulf Organisation for Reasearch and 
Wirya Shawkat L. et al.: Leed rating system barriers in the construction sector In...

Development) in cooperation with the University of Pennsylvania, by T.C. Chan Center at (GSAS, 2015). GSAS most important feature is that, considers the environmental, social- economic, and cultural factors, which has its identity from other parts of the world. Many other countries in the region became interested to this rating system such as Kuwait, Saudi Arabia, Sudan and Jordan, as a proper green building code for the region, (Zafar,2016). The ARZ Green Building Rating System is one of the green building rating systems which have developed by LGBC (Lebanon Green Building Council) in association with the International Finance Corp. the system goal is focusing on reduce environmental impacts and increment of operation efficiency. The ARZ rating system assessor accredited by LGBC takes in account the water consumption and energy usage, Techniques and technologies, as well as the procedures that apply in the building and then rate the building according to how well the building matches the list of the ARZ rating system requirements (Zafar,2016).

\section{Conclusions and Recommendations}

The paper tried to find the most important factors that affect the application of Sustainable construction in the Northern Iraq as a blooming federal region in Iraq, in the construction sector, after 2003. The paper identified the most important barriers front of the sustainable construction in the buildings based on literature review and theoretical analysis. The literature review came out with international list of barriers that could be hinders front of the sustainability in building construction sector. Also, to examine the ability of applying LEED green rating system in Northern Iraq as one of the international standards, and how it could be useful. The paper employed that to apply it in a questionnaire in order to get the opinion of professional people in this field or to find other barriers, which could be limited to the region of the study out of the international barriers. In spite of the lack of the professionals in the field of sustainable building construction and design in the region of the study, the result of the questionnaire was compared with the obtained data through theoretical analysis, and the results demonstrate the following:

1. the most important barriers in sustainable building construction is the Initial cost and lack of regulation and legislations regarding the issue of sustainability in the construction specifications.

2. The international barriers in the sustainable construction in all around the world are the same barriers in the region of the study.

3. LEED green rating system is possible to be employed as sustainable rating system in construction projects, at Northern Iraq, but with some 
Wirya Shawkat L. et al.: Leed rating system barriers in the construction sector In...

developments to be adapted to the climatic characteristic of the region and some modification to harmonize the socio-cultural needs.

4. The paper demonstrated that the most prior and important aspect in sustainability three aspects is the social aspect, and then follow by environmental aspect and in the end with economic aspect. These priorities highlighting the type of the society were the social factor is the most important and then the environmental factor and finally the economic factor. The paper interpretation about putting the environmental in foreground upon economic is that the professionals in the field of sustainability are prior the environmental issue due to their awareness about the global challenges, and the danger of continuing with the way that don't stop that environmental impact. However, the economic issue was one of the priorities as well.

5. The study demonstrated that sustainable construction practice in the Northern Iraq poor and many actions should be taken in order to develop this situation. This could be done with two main ways; the legislations and new regulation in the building construction sectors enforce the people to apply sustainable way in construction sector. Another way is to promote the awareness about the sustainability and the benefit behind applying this system.

It should be suggested that the Sustainable construction should take in consideration the passive design strategies more than the active design and adding new technologies, in order to reduce the capital cost of the construction. In the same time this way will reduce the negative effects on the Northern Iraq government and private sector budget. For example using cavity wall in the design could be cheaper than using extra materials added to the building as insulation materials and the periodic maintenance for these materials could be costly. Putting in mind that the most items which makes the sustainable construction costly are imported materials with new techniques.

Another suggestion is to create specific green rating system, based on the applicable items with the Northern Iraq, utilizing other types of rating system that used in other countries. For example, using the unique credits of culture and vernacular design from QSAS, and involve the energy and water conservation credits for ARZ_LGBC, with some important credits of new design strategies for large scale projects in different categories of buildings could be taken from PRS. In addition to the items that could be taken from LEED and BREEAM, in order to get suitable applicable green rating system, in Northern Iraq.

The collaboration with neighbor countries which have experienced these systems will be helpful, especially Turkey. Turkey has many big companies working in this field at Northern Iraq. To get an experience from Turkish 
Wirya Shawkat L. et al.: Leed rating system barriers in the construction sector In...

legislations and regulations about green rating system in building construction will be helpful because of the similarity in climatic character of many parts of Turkey with Northern Iraq, in addition to that, the similarity in the socio-cultural level between Turkey and Northern Iraq as well.

\section{References}

Adams, W. M., (2006, 29-31, January).The Future of Sustainability: Re-thinking Environment and Development in the Twenty-first Century. Report presented to the IUCN Renowned Thinkers Meeting IUCN, the world conservation union.

Al Surf, M. S. (2014). Challenges Facing the Application of Sustainability to Housing in Saudi Arabia. Ph.D. Thesis, Queensland University of Technology, Brisbane, Queensland. Australia: Queensland University of Technology

Appleby, P. (2011). Integrated Sustainable Design of Buildings. London, UK: Earthscan

Asif, M., Muneer, T. \&Kubie, J. (2005). Sustainability analysis of window frames. Building Services Engineering Research \& Technology 26(1): 71-87.

Babbie, E. R. (1990). Survcy research methods. Belmont, CA, USA : Wadsworth.

Bosher, L., Carrillo, P., Dainty, A., Glass, J. and Price, A. (2007). Realizing and resilient and sustainable built environment: towards a strategic agenda for the United Kingdom. Disasters, 31 (3), 236-255

BREEAM (2009). BREEAM: The Environmental Assessment Method for Buildings around the World. [Retrieved] on $1^{\text {st }}$ of March, 2017 from www.breeam.org

Bromley, D. B. (1990). Academic contributions to psychological counselling: I. A philosophy of science for the study of individual cases. Counseling Psychology Quarterly, 3(3), 299-307.

Castillo, R., and Chung, N. (2005). The value of sustainability. Stanford, California, USA: Center for Integrated Facility Engineering (CIFE) Department of Energy: Washington, D. C. DOE, Annual Energy Review 2000. (2001). Energy Information Administration, U.S.

Du Plessis, C., 2007. A strategic framework for sustainable construction developing countries. Construction Management and Economics, 25, 67-76.

Dzokoto, S.D., Dadzie, J. (2013, 12-14, August). Barriers to sustainable construction in the Ghanaian construction industry: consultants perspectives In: Laryea, S. and Agyepong, S. (Eds) presented on Process 5th West Africa Built Environment Research (WABER) Conference. Accra, Ghana, 223-234.

Edum, F. T. and Price, A. D. F. (2009). A social ontology for appraising sustainability of construction projects and developments. International Journal of Project Management, 27 (4), 313-322.

Gunatilake, S. (2013). The Uptake and Implementation of Sustainable Construction: Transforming Policy into Practice. Ph.D. Thesis, University of Central Lancashire, Preston, England. England: University of Central Lancashire

Häkkinen, T., Belloni, K. (2011). Barriers and drivers for sustainable building, Building Research and Information, 39(3), 239-255.

Hendriks, C. F.(2001). Sustainable construction. Boxtel, Netherland: Ęneas Technical Publishers. 
Wirya Shawkat L. et al.: Leed rating system barriers in the construction sector In...

Hill, R. C. and Bowen, P. A. (1997). Sustainable construction: principles and a framework for attainment. Construction Management and Economics, 15 (3), 223-239 http://www.tucsa.org/images/yayinlar/makaleler/SurdurulebilirYapilasma-Sorunu-ve-Celik.pdf

Huovila, P. and Richter, C. (1997, August, 19). Life cycle building design in 2010. Presented to 11th International Conference on Engineering Design - ICED 97. Tampere University of Technology, Finland.

IISBE (2009). International Initiative for a Sustainable Built Environment. [Retrieved] on $27^{\text {th }}$ Feb., 2017 from www.iisbe.org. Indicators Research, 87(2), PP: 211-221.

Kirk, S.J. and Dell'Isola, A.J. (1995). Life cycle costing for design professionals. New York, USA: McGraw-Hill.

Liu, A. M. M., 2006. The framework underpinning conflicting keys in sustainability: harmony-in-transit. Property Management, 24 (3), 219-231.

McConville J. R. (2006). Applying Life Cycle Thinking to International Water and Sanitation Development Projects: An assessment tool for project managers in sustainable development work. Master thesis, Houghton, Michigan. Michigan Technological University. USA: Michigan Technological University.

Nazirah Zainul Abidin, Christine L. Pasquire, (2005) "Delivering sustainability through value management: Concept and performance overview", Engineering, Construction and Architectural Management, Vol. 12 Issue: 2, pp. 168-180

Nelms, C., Russel, A.D., Lence, B.J. (2005). Assessing the performance of sustainable technologies for building projects. Canadian Journal for Civil Engineering, 32, 114-128.

Osaily, N.Z. (2010). The key Barriers to Implementing Sustainable Construction in West Bank -Palestine. Master Thesis, Robert Kennedy College / Zurich, University of Wales. UK: University of Wales.

Ozdil, O.S. (2010). Sürdürülebilir Yapılaşma Sorunu ve Çelik (Sustainable Building Issues and Steel). [Retrieved] $4^{\text {th }}$ of March, 2017 from

Parkin, S., Sommer, F. and Uren, S. (2003). Sustainable development: understanding the concept and practical challenge. Proceedings of the Institution of Civil Engineers, Engineering Sustainability, 156 (1), $19-26$.

Pearce, D. (2003). The social and economic value of construction: The construction industry's contribution to sustainable development. London, UK: $n$ CRISP - The Construction Industry Research and Innovation Strategy Panel. research design (pp. 1538-1541). Thousand Oaks, CA,USA: Sage

Robichaud, L. B. and Anantatmula, V. S. (2011). Greening project management practices for sustainable construction. Journal of Management in Engineering, $27(1), 48-57$.

Rydin,Y., Amjad, U., Moore, S., Nye, M., Withaker, M. (2006) . Sustainable Construction and Planning: The Academic Report. London School of Economics, London, England: Centre for Environmental Policy and Governance, The LSE SusCon Project, CEPG.

Sjostrom, C. and Bakens, W. (1999). CIB Agenda 21 for sustainable construction: why, how and what. Building Research and Information, 27 (6), 347-353.

Soderberg, N.E., Phillips, D.L. (2015). Task Force Report: State- building in Iraqi Kurdistan. New York, United State: Institute for the Study of Human Rights, Columbia University

U.S. Green Building Council.(2006). Building Design and Construction's White Paper on Sustainability: A Report on the Green Building Movement. [Retrieved] on $4^{\text {th }}$ 
Wirya Shawkat L. et al.: Leed rating system barriers in the construction sector In...

of March, 2017 from http://www.usgbc.org/Docs/Resources. UN-Agenda 21. (2004). New York, USA: NY.

Unated Nations (2004) UN-Agenda 21, USA: New York.

UNEP (2003). Sustainable building and construction: facts and figures. UNEP. [Retrieved] on $3^{\text {rd }}$ of March, 2017 from: http://www.uneptie.org/media/review/vol26no2-3/005-098.pdf

USAID (2008). Kurdistan Region Economic Development Assessment- Final Report. USA: RTI International

Williams, K., Dair, C. (2007). What is stopping sustainable building in England? Barriers experienced by stakeholders in delivering sustainable developments. Sustainable development, 15 (3),135-147.

Winston, N., \& Eastaway, M. P. (2008). Sustainable Housing in the Urban Context: International Sustainable Development Indicator Sets and Housing, Social Indicators Research, volume 87, issue 2, pp.211-227,

Zafar, S. (2016). Green Building Rating System in Middle East. [Retrieved] on $10^{\text {th }}$ of April, 2017 from :http://www.cleantechloops.com/green-rating-middle-east/

Zainal, Z. (2007). Case study as a research method. Jurnal Kemanusiaan, (9), 1-6. Zainul abidin, N., Pasquire, C. L. (2005). Delivering sustainability through value management: Concept and performance overview. Engineering, Construction and Architectural Management, 12(2), 168-180 